Vol. 5, No. 1, 2019

\author{
Viktor Uvarov ${ }^{1}$, Serhii Bespalov ${ }^{2,3}$ \\ 1. G.V. Kurdyumov Institute for Metal Physics of the NAS of Ukraine, Ukraine, Kyiv, Academician Vernadskii \\ Boulevard, 36, E-mail: uvarov@imp.kiev.ua \\ 2. Presidium of NAS of Ukraine, Ukraine, Kyiv, Volodymyrska street, 54, \\ E-mail: bespalov@nas.gov.ua \\ 3. Technical Center of NAS of Ukraine, Ukraine, Kyiv, Pokrovska street, 13
}

\title{
PREDICTION OF TRIBOLOGICAL PROPERTIES OF STRUCTURAL STEELS USING ARTIFICIAL NEURAL NETWORKS
}

Received: June 12, 2019 / Revised: June 25, 2019 / Accepted: June 26, 2019

(C) Uvarov V., Bespalov S., 2019

Abstract. The effect of quenching temperature on wear resistance of $40 \mathrm{Kh}$ steel after tempering has been investigated. It was found that compared to standard heat treatment, quenching from $1050{ }^{\circ} \mathrm{C}$ and high temperature tempering increase its tribological characteristics. The character of fracture of the contacting surfaces was studied. It was shown that in the specimens quenched from $860{ }^{\circ} \mathrm{C}$ and tempered, the fracture of the contact surface occurs by the mechanisms of smooth splitting and delamination with plastic deformation. Increasing the quenching temperature to $1050{ }^{\circ} \mathrm{C}$ along with high temperature tempering changes the character of the contact surface destruction. The areas with a distinctive microstructure appear on the surface exhibiting substantially higher wear resistance during friction as compared to the surrounding volume. The structuralgeometrical parameters characterizing the roughness and bearing capacity of the contact interaction surface were analyzed. It was found that increasing the quenching temperature to $1050{ }^{\circ} \mathrm{C}$ allows to reduce the surface roughness and increase the bearing capacity. Using the methods of optical and transmission electron microscopy, the peculiarities of forming the microstructure of the investigated steel were studied, depending on the temperature conditions of the thermal treatment. It was shown that raising the quenching temperature to $1050{ }^{\circ} \mathrm{C}$ increases the austenitic grain size, enhances nonuniformity of carbon distribution, which leads to the formation of large needle-shaped crystals of lath martensite with microtwin boundaries inside. This, in turn, promotes the formation at high tempering of non-uniformly distributed aggregates of coarse carbides at these microtwin boundaries. The aggregates form areas of microstructure with increased resistance to plastic deformation processes. That is, the morphology of the carbide phase is one of the main factors that determine the tribological characteristics of steel, namely roughness, structural-geometrical parameters and bearing capacity of the surface. The expediency of using artificial neural networks for prediction of tribological properties of structural steels was shown. According to the results of modeling the structural-geometrical parameters of the surface and the roughness characteristics, the bearing capacity of the $40 \mathrm{Kh}$ steel surface during friction was predicted.

Keywords: steel microstructure, carbide phase, wear resistance, surface bearing capacity, structural-geometrical parameters of the surface, neural network modeling.

\section{Introduction. Problem Statement}

The development of mechanical engineering requires an increase in the power, reliability, and durability of machine parts and mechanisms under their conditions of operation in gas and liquid environments, at low and high temperatures.

The available data on the physical and mechanical properties of the materials make it possible to provide sufficient strength for machine parts with a guarantee of failure-free operation. But the most 


\section{Viktor Uvarov, Serhii Bespalov}

common cause of failure of machine parts is not complete fracture, but wear and damage to the working surfaces due to friction. It is the damaging of the surface that disrupts the operation mode for the parts of the friction units, causes additional loads, percussion in the joints and vibrations, causing unacceptable noise, sticking and jamming, which in the end causes accidents.

$80 \ldots 85 \%$ of machines and mechanisms fail due to wear of parts, and having them idle when repairing moving joints results in reduced efficiency by $15 \ldots 20 \%$ [1-6]. Consequently, the durability, reliability and lifetime of machines are in many cases related to the wear resistance of the materials from which they are made [7-10]. Therefore, minimization of wear is one of the central segments in solving problems such as energy savings, reducing outgoings of material, and ensuring the reliability and safe operation of mechanical systems. In this regard, further research in the field of tribotechnical materials science, which can deepen existing and find new ways to reduce friction losses and wear by increasing the wear resistance of machine parts and mechanisms, is of particular importance. This confirms the need to study the general patterns of fracture in the conditions of contact interaction and their relationship with the features of structure formation during the heat treatment of parts. The experience gained here allows to significantly reducing the cost of restoring and repairing mechanisms and machines, significantly improving their safety and productivity [11-14].

At the same time, the process of tribological research in most cases requires the testing of a large number of specimens, the use of expensive experimental equipment, and the interpretation of results, which is often difficult. Therefore, to predict the workability of materials under friction and to control the structural-phase state of the contact surfaces which would provide the required level of physical and mechanical properties, it is important to combine the results of experiments with modern computer simulation.

\section{Review of Modern Information Sources on the Subject of the Paper. Objectives and Problems of Research}

Currently, artificial neural networks (ANNs) are increasingly used to solve a wide range of practical tasks, such as process modeling, predicting, regulation and optimization of decision-making, analysis of property change monitoring, pattern recognition, signal processing, control, etc. [15-17]. ANN is a software or hardware embodiment of mathematical models that are built on the principle of the organization and operation of biological neural networks, namely nerve cell networks of a living organism, and is a computer technology closely related to neurophysiology, mathematics, statistics, physics, and engineering.

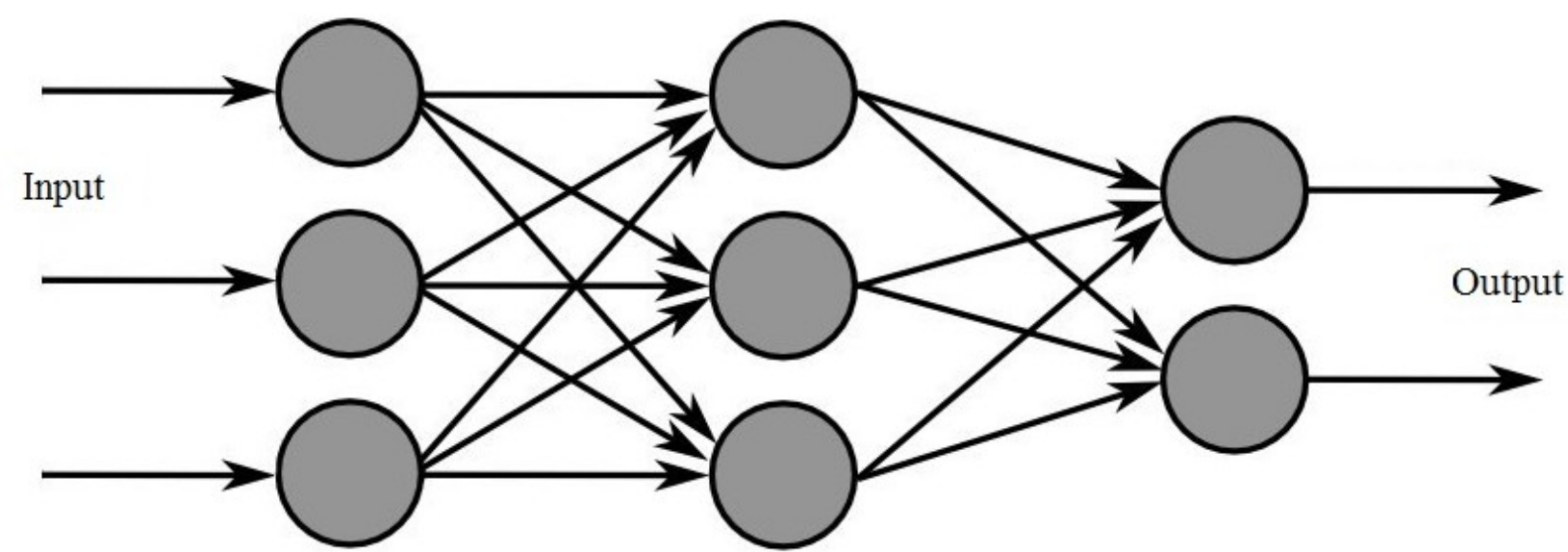
Input layer
Hidden Layer
Output layer

Fig. 1. Scheme of building a typical artificial neural network [18]

The scheme of the typical construction of an ANN is shown in Fig. 1. Neural networks are groups of neurons in the form of layers interconnected in a specific way. Although there are networks that contain 


\section{Prediction of Tribological Properties of Structural Steels Using Artificial Neural Networks}

only one layer or even one element, most implementations use networks that contain at least three types of layers: input, hidden and output. Input layer neurons receive experimental data either from input files or directly from electronic sensors. The output layer sends the information directly to the external environment to a secondary computer process or another device. Between these two layers may be one or more hidden ones that contain a large number of differently connected neurons. The inputs and outputs of each of the hidden neurons are connected to all other neurons. The type of connection between neurons has a great impact on the operation of the network and there are two types: the first, which excites neurons, the so-called mechanism of summation, and the second, which transmits inhibiting signals, called the mechanism of subtraction [18].

The direction of connection from one neuron to another is an important aspect of neural network functioning. In an ANN of direct propagation, each neuron of the hidden layer receives signals from the neurons of the previous one and, after performing operations on the signals, transmits its output to the neurons of the next layers, providing the signal forward to the output. In addition to direct propagation networks, in which the signal propagates strictly from the input layer to the output layer, there are feedback (backpropagation) networks [19] in which the output of neurons is directed to neurons of the previous layer.

The most important feature of an ANN is the ability to learn from examples, numerical experimental data, or environmental parameters. ANN learning is a process in which the neural network parameters are adjusted by modeling the environment into which the network is embedded. As a result of the learning, the architecture of the neural networks is adapted, their efficiency is increased, and the algorithm for solving real tasks is optimized. The type of learning is determined by how to adjust these parameters. This definition of the learning process involves the following sequence of actions [17]:

-Excitation results (data) come from the external environment to ANN.

-As a result, the ANN's free parameters change, that is, its setting is changed.

- After changing the internal architecture ANN responds to the excitation in another way.

But at present, there is no universal learning algorithm that is suitable for all ANN types. There is only a set of tools, represented by a large number of learning algorithms, each with its disadvantages and advantages [17].

Up to now, many variants of ANN and their modifications have been created, which are increasing every year [20]. Since neural networks are a sufficiently efficient apparatus for modeling complex processes and have universal approximating properties, it makes sense to use them to solve prediction tasks [21]. This contributes to their successful use for solving a wide range of applied tasks of classification, control, managing and connection [22-25], in digital technology [26], systems of technical vision [27, 28], economics [29, 30], with speech recognition [31, 32], design of Intelligent Home systems [33], implementation of intelligent agents for information collection and virus search [34-37], for the analysis of electromechanical systems [38, 39], etc. Most existing ANN software packages allow the user to add, subtract, and manage connections as desired and can be made both exciting and inhibiting by constantly adjusting the connection settings. An important factor in the network operation is the choice of the actual number of neurons and the necessary connections between them [40].

The solution of the vast majority of materials science tasks is based on the study of microstructure, phase composition, the complex of mechanical properties of machine parts, as well as their change during operation and depending on its conditions. Given this, the authors of the works [41, 42] have shown that one of the most promising tools for solving applied problems of material science is the use of computer neural network modeling. Therefore, the purpose of this work was to determine the possibility of using artificial neural networks to predict the tribological properties of structural materials.

\section{Main Material Presentation}

The object of research was industrially smelted structural steel $40 \mathrm{Kh}$ of the following chemical composition: $0.41 \% \mathrm{C}, 0.45 \% \mathrm{Mn}, 0.33 \% \mathrm{Si}, 0.98 \% \mathrm{Cr}, 0.054 \% \mathrm{Ni}, 0.03 \% \mathrm{~S}, 0.03 \% \mathrm{P}$. Considering the 


\section{Viktor Uvarov, Serhii Bespalov}

influence of temperature-time conditions of heat treatment on the morphology of the martensite and carbide phases, which influences the mechanical characteristics of steels $[43,44]$, the quenching of the investigated steels was carried out in oil from a standard temperature of $860{ }^{\circ} \mathrm{C}[45]$ and $1050{ }^{\circ} \mathrm{C}$.

The wear resistance was determined on a 2070 CMT-1 machine according to the "disk-pad" scheme in the mode of dry sliding friction at a load of $300 \mathrm{~N}$ and a sliding speed of $0.5 \mathrm{~m} / \mathrm{s}$. The test time was 10 hours. The counter-body material was steel 45 with a hardness of $50-52$ HRC. Wear resistance was evaluated hourly by weight loss. The microstructure was examined by optical and transmission electron microscopy. Stereometric studies of surface microtopography were performed on a computerized Rank Taylor Hobson stereometric profilometer with a Taliscan scanning head with a quantization step of $1-$ $2 \mu \mathrm{m}$. The structure of the contact interaction surface was studied by scanning electron microscopy (SEM). The hardness was measured by the Brinell method, and the microhardness by the scratching method on the PMT-3 microhardness tester under a load of $20 \mathrm{~g}$ with a step of $2-4 \mu \mathrm{m}$ according to the method defined in [46].

Quenching from $1050{ }^{\circ} \mathrm{C}$ compared to standard heat treatment reduces the Brinell hardness of tempered $40 \mathrm{Kh}$ steel from 2636 to $2499 \mathrm{MPa}$. At the same time, tribological tests showed (Table 1) that, notwithstanding the decrease in hardness, raising the quenching temperature to $1050{ }^{\circ} \mathrm{C}$ decreases the wear intensity of the specimens of the investigated steel from 3.719 to 3.012 .

Table 1

Dependence of the weight wear intensity $I_{m}$ on the quenching temperature of $40 \mathrm{Kh}$ steel after tempering

\begin{tabular}{|c|c|c|}
\hline Quenching temperature $t,{ }^{\circ} \mathrm{C}$ & $I_{m} \cdot 10^{-8}$ & Brinell hardness, MPa \\
\hline 860 & 3.719 & 2636 \\
\hline 1050 & 3.012 & 2499 \\
\hline
\end{tabular}

SEM studies of the contact surface before the wear test showed (Fig. 2a) that it is independent of the heat treatment conditions and is identical for both studied quenching temperatures.

Contact interaction promotes the formation of zones of local plastic deformation on the friction surface of $40 \mathrm{Kh}$ steel specimens tempered after quenching from $860^{\circ} \mathrm{C}$. These zones are elongated in the direction of the counter-body motion (Fig. 2b). On the surface, one can see scratches, chips, and the dimples as signs of peeling of carbides and their separation from the matrix, which are elongated in the direction of sliding. The fracture of the friction surface occurs by mechanisms of smooth delamination with plastic deformation and splitting.

Increasing the quenching temperature to $1050{ }^{\circ} \mathrm{C}$ with high temperature tempering changes the character of the surface of the contact interaction, which becomes non-uniform (Fig. 2c). This change is obviously related to the peculiarities of the fracture processes occurring in individual parts of the surface. In most of the contact area, there are local sections with dimensions that do not coincide with any elements of the microstructure. The fracture in these places occurs by smooth delamination with signs of plastic deformation (scratches, cleavage, tearing away of carbides from the matrix and their crumbling).

This indicates that the plastic deformation of the sub-surface layers, which are apparently saturated with uniformly distributed carbide inclusions of various sizes, is responsible for the formation of such sections. Larger carbides crumble from the surface and may subsequently cause its microfracture. The smaller ones dissociate into the surrounding matrix while the plastic deformation. In this case, the situation corresponds to the peculiarities of fracture of the contact surface of the $40 \mathrm{Kh}$ steel specimens after quenching from $860^{\circ} \mathrm{C}$ and high temperature tempering.

In other sections of the contact surface, the total area of which is about $15 \%$ of the total contact surface area, the fracture is also ductile. However, the microstructure of such sections has a much greater resistance to fracture upon contact interaction. This is obviously related to the change in the morphology of the carbides, which in this case have a larger aggregation and size, and also stronger bonds to the matrix. 
Prediction of Tribological Properties of Structural Steels Using Artificial Neural Networks
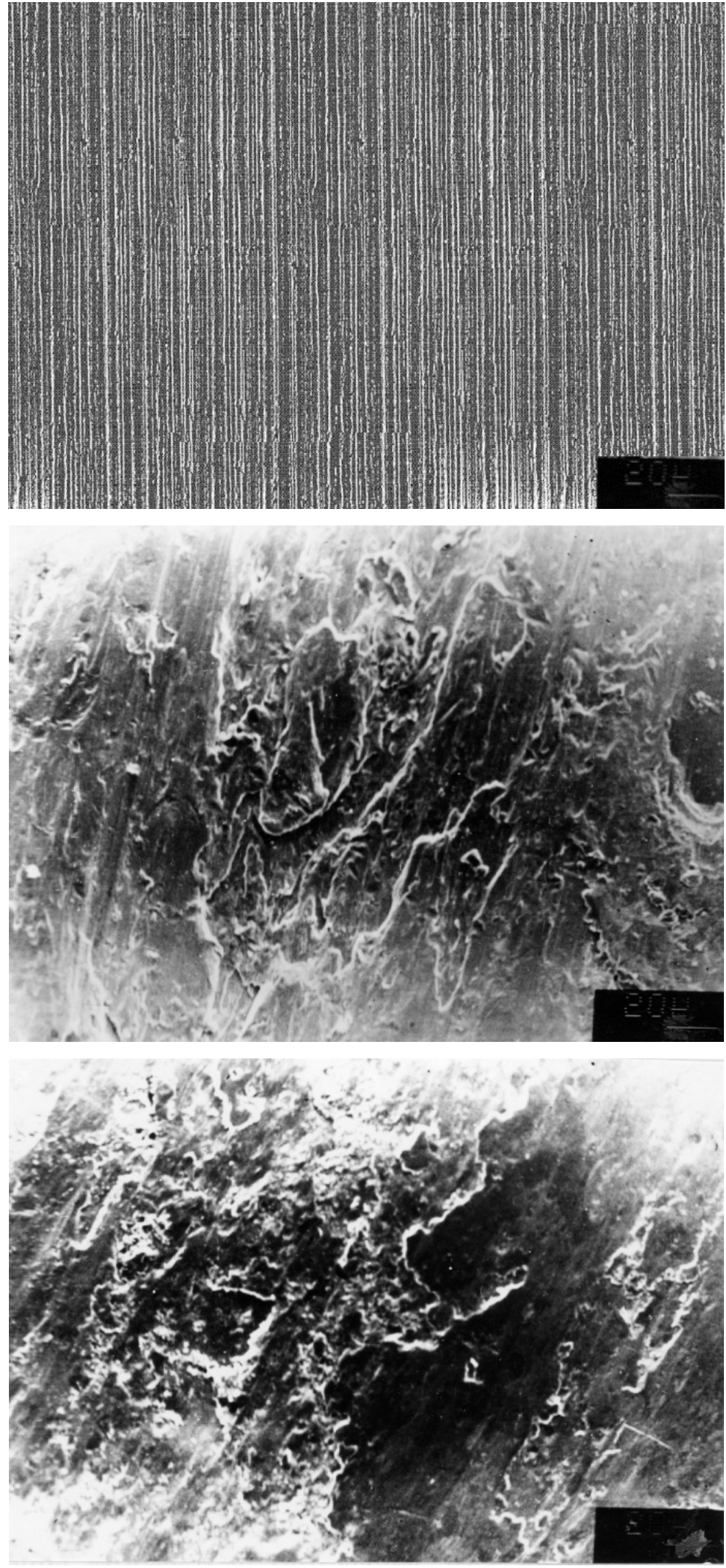

$\mathrm{c}$

Fig. 2. Contact surfaces of $40 \mathrm{Kh}$ steel specimens after quenching from a temperature $860(\mathrm{a}, \mathrm{b})$ and $1050{ }^{\circ} \mathrm{C}(\mathrm{b})$ and tempering at $600{ }^{\circ} \mathrm{C}$ : (a) after grinding before tribological tests; (b, c) after tribological tests 


\section{Viktor Uvarov, Serhii Bespalov}

Stereometric studies of friction surface microtopography gave structural-geometrical parameters (Table 2) characterizing the roughness, as well as discrete asymmetric images of the surface of specimens of the investigated steel after grinding of the specimens quenched from $860{ }^{\circ} \mathrm{C}$ and tempered at $600{ }^{\circ} \mathrm{C}$ (Fig. 3a) and after tribological tests of the specimens quenched from $860^{\circ} \mathrm{C}$ and $1050{ }^{\circ} \mathrm{C}$, respectively, and tempered at $600{ }^{\circ} \mathrm{C}$ (Fig. 3b, c). The obtained results indicate that the initial roughness of the parts of the moving joints does not depend on the conditions of heat treatment, i.e. it is similar for both investigated quenching temperatures. Thus, the initial roughness does not determine the geometry of the surface in the contact area formed during friction. This confirms the results of works [47 - 49], in which it is shown that under different conditions and in different friction couples after pre-working, regardless of the initial roughness, the same, equilibrium roughness is established (Fig. 4).
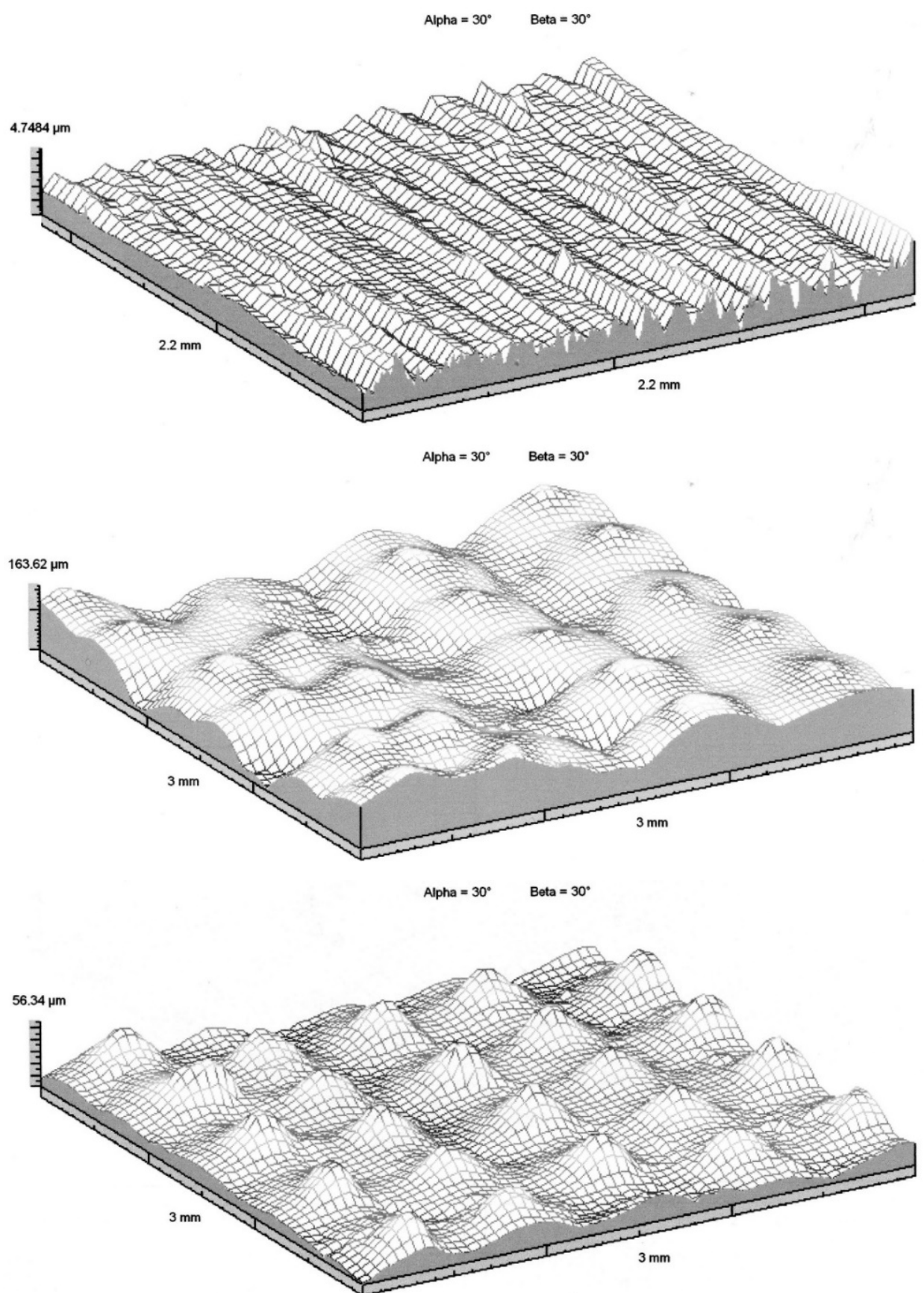

$\mathrm{c}$

Fig. 3. Discrete asymmetric images of the $40 \mathrm{X}$ steel specimens surface: (a) after grinding of the specimens quenched from $860{ }^{\circ} \mathrm{C}$ and tempered at $600^{\circ} \mathrm{C}$; (b, c) after tribological tests of the specimens quenched from $860{ }^{\circ} \mathrm{C}$ and $1050{ }^{\circ} \mathrm{C}$, respectively, and tempered at $600^{\circ} \mathrm{C}$ 


\section{Prediction of Tribological Properties of Structural Steels Using Artificial Neural Networks}

Carrying out the analysis of certified parameters according to ISO $13565[50,51]$ for the studied surfaces made it possible to construct curves that determine their "bearing capacity" (Fig. 5). As can be seen, the maximum bearing capacity has a polished surface (Fig. 5a). But in the process of operation, due to the formation of equilibrium roughness, the capacity changes and, as in the case of roughness, its certain equilibrium value is established.

Comparison of the samples after tribological tests showed that raising the quenching temperature to $1050{ }^{\circ} \mathrm{C}$ (Fig. 3c; 5c; Table 2) contributes to the reduction of the roughness and the increase of the bearing capacity of the surface of the tempered $40 \mathrm{Kh}$ steel specimens during friction as compared to the specimens quenched from $860^{\circ} \mathrm{C}$ (Fig. 3b; 5b; Table 2).

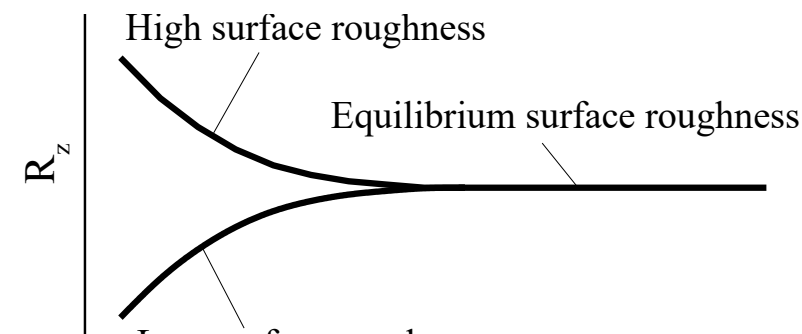

Low surface roughness
Fig. 4. Effect of operating time (t) on the average distance based on the ten highest peaks and lowest valleys $\left(R_{z}\right)$ of the surfaces of moving joint parts [48]

$\mathrm{t}$
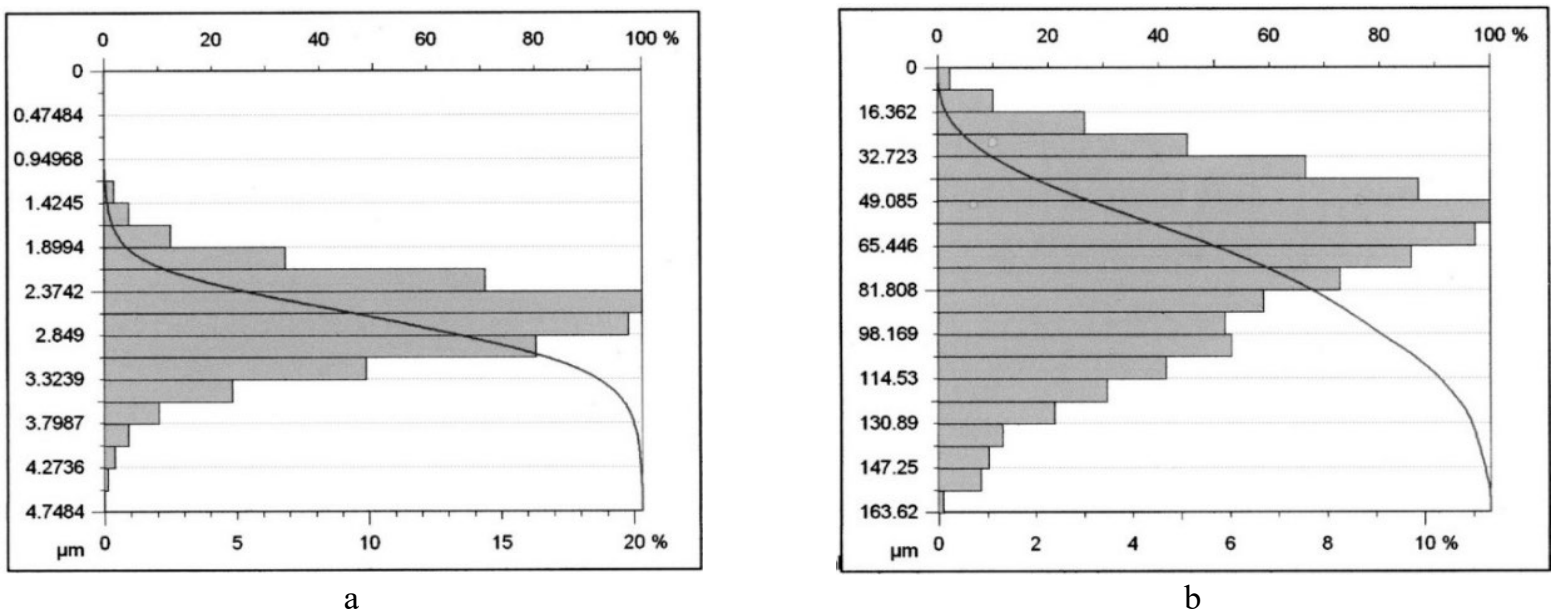

a

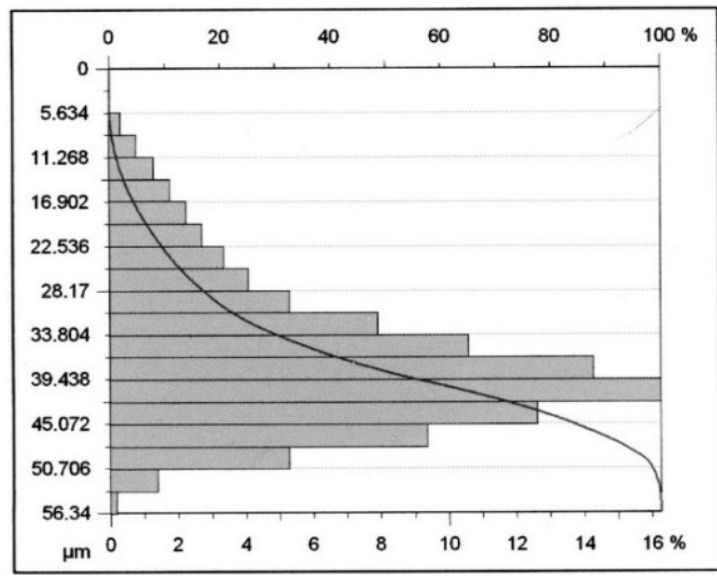

c

Fig. 5. Amplitude distribution of the surface profile with superimposed image of the bearing surface of $40 \mathrm{Kh}$ steel specimens: (a) after grinding before tribological tests of the specimens quenched from $860{ }^{\circ} \mathrm{C}$ and tempered at $600{ }^{\circ} \mathrm{C}$; (b) after tribological tests of the specimens quenched from $860{ }^{\circ} \mathrm{C}$ and tempered at $600{ }^{\circ} \mathrm{C}$; (c) after tribological tests of the specimens quenched from $1050{ }^{\circ} \mathrm{C}$ and tempered at $600{ }^{\circ} \mathrm{C}$ 
Viktor Uvarov, Serhii Bespalov

Table 2

Structural-geometrical surface parameters (according to ISO 4288) of the studied 40Kh steel specimens before and after the wear test

\begin{tabular}{|c|c|c|c|}
\hline \multirow{4}{*}{ Parameter } & \multicolumn{3}{|c|}{ State } \\
\hline & before the wear test & \multicolumn{2}{|c|}{ after the wear test } \\
\hline & \multicolumn{3}{|c|}{ Quenching temperature, ${ }^{\circ} \mathrm{C}$} \\
\hline & 860 & 860 & 1050 \\
\hline \multicolumn{4}{|c|}{ Amplitude parameters } \\
\hline $\mathrm{Sa}$ & $0.3697 \mu \mathrm{m}$ & $24.879 \mu \mathrm{m}$ & $7.1195 \mu \mathrm{m}$ \\
\hline $\mathrm{Sq}$ & $0.47311 \mu \mathrm{m}$ & $30.475 \mu \mathrm{m}$ & $9.1392 \mu \mathrm{m}$ \\
\hline $\mathrm{Sp}$ & $2.6779 \mu \mathrm{m}$ & $69.946 \mu \mathrm{m}$ & $16.647 \mu \mathrm{m}$ \\
\hline $\mathrm{Sv}$ & $2.0705 \mu \mathrm{m}$ & $93.669 \mu \mathrm{m}$ & $19.7 \mu \mathrm{m}$ \\
\hline St & $4.7484 \mu \mathrm{m}$ & $163.62 \mu \mathrm{m}$ & $58.34 \mu \mathrm{m}$ \\
\hline Ssk & -0.14415 & -0.43799 & 0.91073 \\
\hline Sku & 3.7171 & 2.647 & 3.5548 \\
\hline $\mathrm{Sz}$ & $4.0711 \mu \mathrm{m}$ & $154.47 \mu \mathrm{m}$ & $48.159 \mu \mathrm{m}$ \\
\hline \multicolumn{4}{|c|}{ Area \& volume parameters } \\
\hline STp & $0.1 \%(1 \mu \mathrm{m}$ under the highest peak $)$ & \multicolumn{2}{|c|}{$0 \%(1 \mu \mathrm{m}$ under the highest peak $)$} \\
\hline SHTp & $0.75658 \mu \mathrm{m}(20 \%-80 \%)$ & $54.729 \mu \mathrm{m}(20 \%-80 \%)$ & $14.141 \mu \mathrm{m}(20 \%-80 \%)$ \\
\hline Smmr & $0.0020705 \mathrm{~mm}^{3} / \mathrm{mm}^{2}$ & $0.093669 \mathrm{~mm}^{3} / \mathrm{mm}^{2}$ & $0.0197 \mathrm{~mm}^{3} / \mathrm{mm}^{2}$ \\
\hline Smvr & $0.0026779 \mathrm{~mm}^{3} / \mathrm{mm}^{2}$ & $0.069946 \mathrm{~mm}^{3} / \mathrm{mm}^{2}$ & $0.036641 \mathrm{~mm}^{3} / \mathrm{mm}^{2}$ \\
\hline \multicolumn{4}{|c|}{ Spatial parameters } \\
\hline SPc & $0 \mathrm{pks} / \mathrm{mm}^{2}(1 \mu \mathrm{m} ; 10 \mu \mathrm{m})$ & \multicolumn{2}{|c|}{$0.55556 \mathrm{pks} / \mathrm{mm}^{2}(1 \mu \mathrm{m} ; 10 \mu \mathrm{m})$} \\
\hline Sds & $1583.5 \mathrm{pks} / \mathrm{mm}^{2}$ & $29.222 \mathrm{pks} / \mathrm{mm}^{2}$ & $255.33 \mathrm{pks} / \mathrm{mm}^{2}$ \\
\hline Str & 0.023256 & 0.17898 & 0.66797 \\
\hline Sal & $0.017221 \mathrm{~mm}$ & $0.2636 \mathrm{~mm}$ & 0.18805 \\
\hline Std & $1.5^{\circ}$ & $63.5^{\circ}$ & $76.0^{\circ}$ \\
\hline \multicolumn{4}{|c|}{ Hybrid parameters } \\
\hline Sdq & $0.048588 \mu \mathrm{m} / \mu \mathrm{m}$ & $0.24774 \mu \mathrm{m} / \mu \mathrm{m}$ & $0.12739 \mu \mathrm{m} / \mu \mathrm{m}$ \\
\hline Ssc & $0.0073931 / \mu \mathrm{m}$ & $0.0411561 / \mu \mathrm{m}$ & $0.018791 / \mu \mathrm{m}$ \\
\hline Sdr & $0.11783 \%$ & $3.0112 \%$ & $0.79474 \%$ \\
\hline \multicolumn{4}{|c|}{ Functional parameters, $0.5 \mu \mathrm{m}$} \\
\hline Sk & $1.0319 \mu \mathrm{m}$ & $47.647 \mu \mathrm{m}$ & $19.283 \mu \mathrm{m}$ \\
\hline Spk & $0.3671 \mu \mathrm{m}$ & $15.239 \mu \mathrm{m}$ & $14.634 \mu \mathrm{m}$ \\
\hline Svk & $0.41572 \mu \mathrm{m}$ & $16.134 \mu \mathrm{m}$ & $4.3158 \mu \mathrm{m}$ \\
\hline $\mathrm{Sr}_{1}$ & $9.2 \%$ & $10.527 \%$ & $16.729 \%$ \\
\hline $\mathrm{Sr}_{2}$ & $90.9 \%$ & $88.337 \%$ & $92.829 \%$ \\
\hline \multicolumn{4}{|c|}{ Functional parameters } \\
\hline Sbi & 0.24301 & 1.2017 & 0.5166 \\
\hline Sci & 1.4447 & 1.353 & 2.0287 \\
\hline Svi & 0.12567 & 0.1215 & 0.68628 \\
\hline
\end{tabular}

The obtained result confirms the data of SEM studies (Fig. 2), as well as the conclusions of the works of many authors, in particular $[52,53]$, which showed that the decrease of altitude parameters of roughness, increase of length of supporting curves of friction surfaces, optimization of areas of peaks and valleys for given friction conditions indicate that structures providing increased resistance of the material to the processes of tribodestruction are formed in the active layer. That is, obtained after quenching from 


\section{Prediction of Tribological Properties of Structural Steels Using Artificial Neural Networks}

elevated temperatures, the microstructure of $40 \mathrm{Kh}$ steel contributes to the formation of a more optimal contact surface relief than after standard heat treatment. Obviously, both the equilibrium roughness and the bearing capacity of the contact surface depend on the microstructure of the test specimens.

Microstructure studies have shown that quenching from a temperature of $860{ }^{\circ} \mathrm{C}$ leads to the formation of austenite grains with an average diameter of $21.5 \mu \mathrm{m}$ in $40 \mathrm{Kh}$ steel (Fig. 6a). As the quenching temperature rises to $1050{ }^{\circ} \mathrm{C}$, the grains whose size varies from 35 to $270 \mu \mathrm{m}$ are observed in the structure of the investigated steel, and the average diameter is $102 \mu \mathrm{m}$ (Fig. 6b).

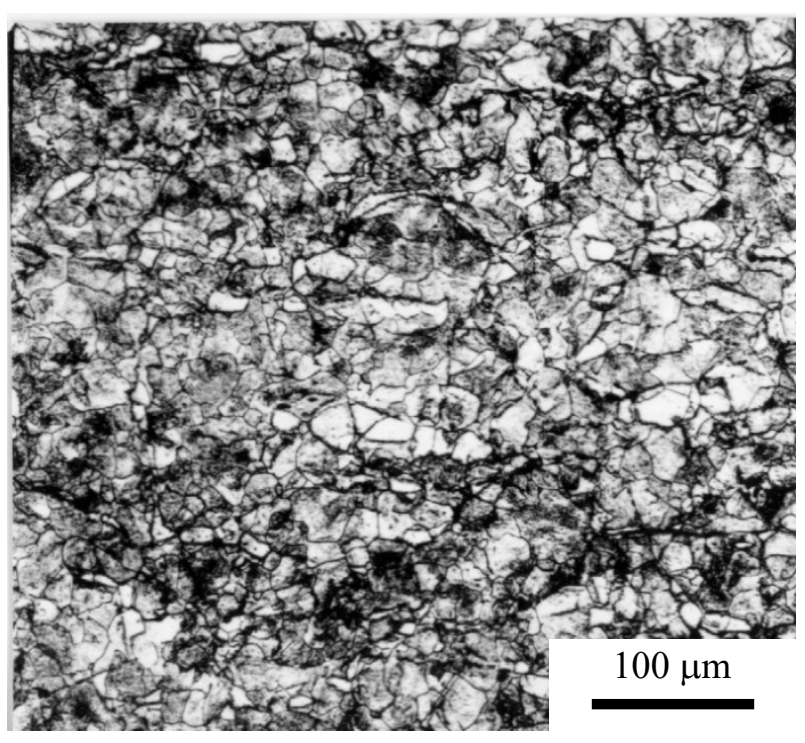

a

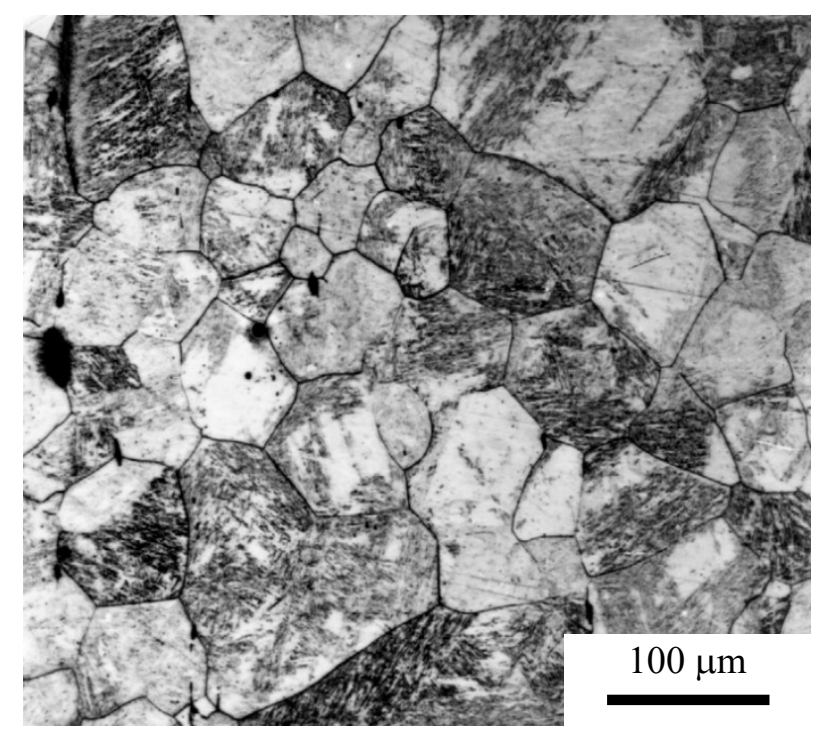

b

Fig. 6. The microstructure of $40 \mathrm{Kh}$ steel after quenching from a temperature 860 (a) and $1050{ }^{\circ} \mathrm{C}$ (b)

Transmission electron microscopic studies revealed martensite of two types, namely packet lath one and needle-shaped one with microtwins inside, in the microstructure of $40 \mathrm{Kh}$ steel specimens quenched from various temperatures (Fig. 7). At the same time, with increasing the quenching temperature to $1050{ }^{\circ} \mathrm{C}$, due to carbon redistribution during the austenitization and grain growth, the size and volume fraction of needle-shaped crystals increase (Fig. 7b) [54].

Analysis of the carbide phase distribution in the tempered specimens showed that after quenching from $860{ }^{\circ} \mathrm{C}$ and high temperature tempering, the equiaxial carbides with an average diameter of $0.05 \mu \mathrm{m}$ were uniformly distributed in the steel structure. Deposition of carbides occurs mainly at the boundaries of the packet martensite cells formed during the tempering and the boundaries of the former needle-shaped martensite crystals, whose width slightly exceeds the cross-section of the martensite laths (Fig. 8a). That is, the microstructure of $40 \mathrm{Kh}$ steel after the standard heat treatment is statistically homogeneous in the microstructural elements. This determines the homogeneity of the contact interaction surface, as discussed above (Fig. 2b).

As the quenching temperature rises to $1050{ }^{\circ} \mathrm{C}$, large crystals of needle-shaped martensite with microtwins inside whose cross-section significantly exceeds the width of the martensite laths of other morphology are formed along with packet martensite. When this structure is tempered, equiaxial carbides are deposited at the boundaries of the former packet martensite laths, as in the case of quenching from $860{ }^{\circ} \mathrm{C}$. But as the temperature of austenitization rises and the width of the laths increases, the tempered microstructure cells become larger and the length of the substructural boundaries decreases. This results in a larger size and a decrease in the number of carbide inclusions, the average diameter of which is $0.055 \mu \mathrm{m}$, although no carbide-free microstructure sections are observed.

During tempering of the needle-shaped martensite, carbide formation occurs inside the crystals at the microtwin boundaries, resulting in a large number of clusters of coarse carbides of elongated shape up to $0.2 \mu \mathrm{m}$ in size (Fig. 8b). The size and location of carbides determine their increased resistance to 


\section{Viktor Uvarov, Serhii Bespalov}

dissociation during the plastic deformation. The microvolumes of material with such morphology are characterized by the presence of internal micro-distortions having higher mechanical properties, in particular, microhardness and higher wear resistance as compared to the surrounding microstructure. The mentioned difference in the morphology of the carbide phase determines the heterogeneity both in structure and in mechanical properties of the contact interaction surface of $40 \mathrm{Kh}$ steel tempered after quenching from $1050{ }^{\circ} \mathrm{C}$, which confirms the results of SEM studies (Fig. 2c).

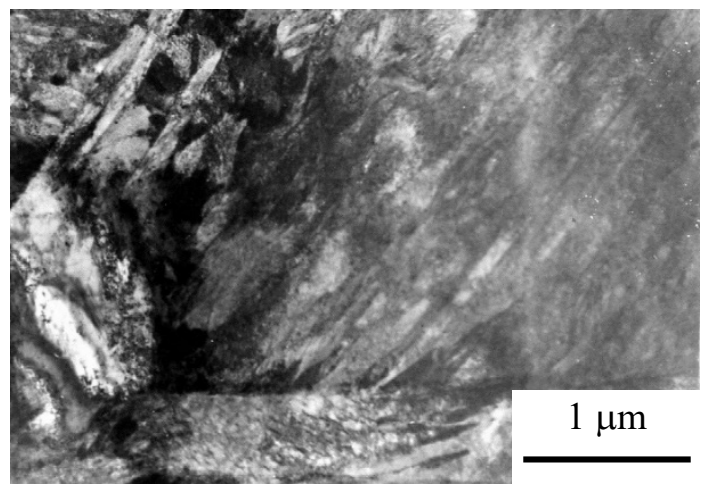

a

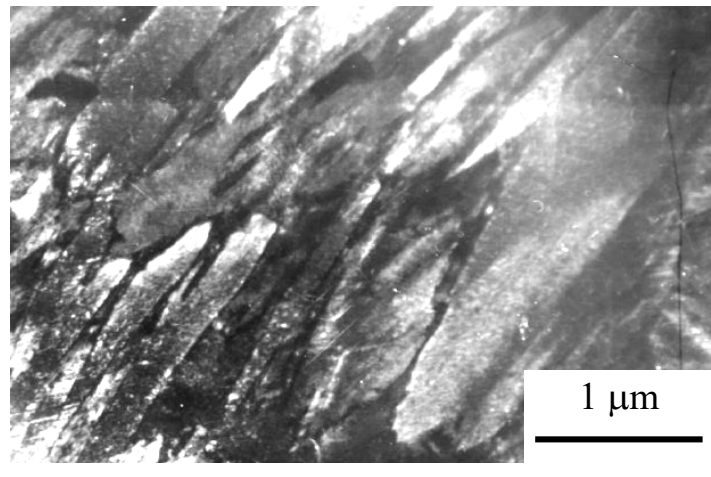

$\mathrm{c}$

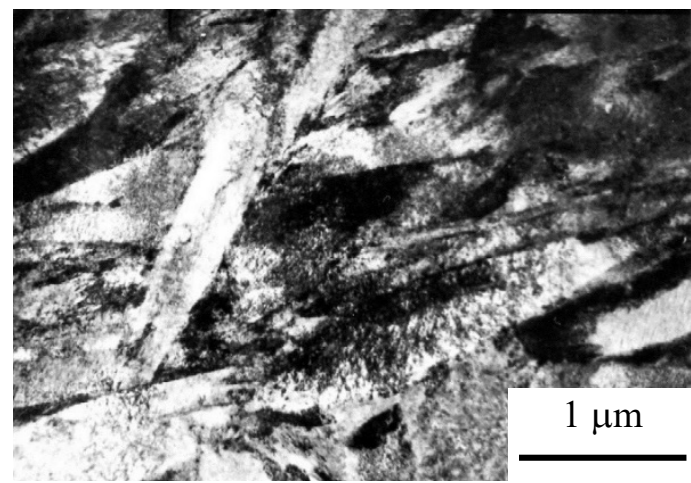

b

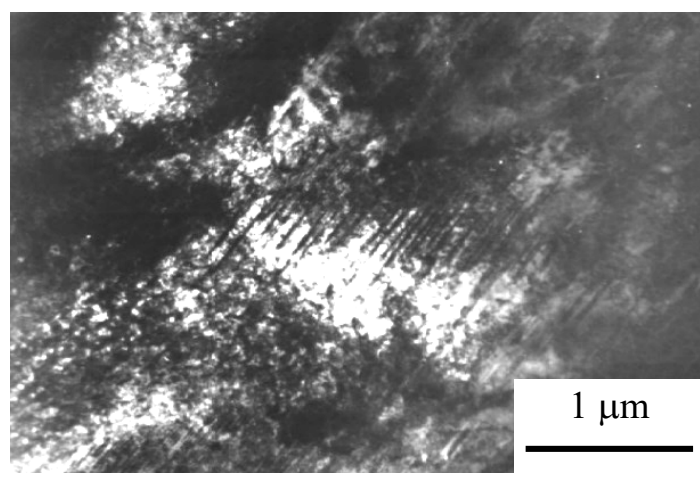

d

Fig. 7. The microstructure of $40 \mathrm{Kh}$ steel quenched from (a, b) 860 and (c, d) $1050{ }^{\circ} \mathrm{C}$ presenting (a, c) package- and (b, d) needle-shaped martensite

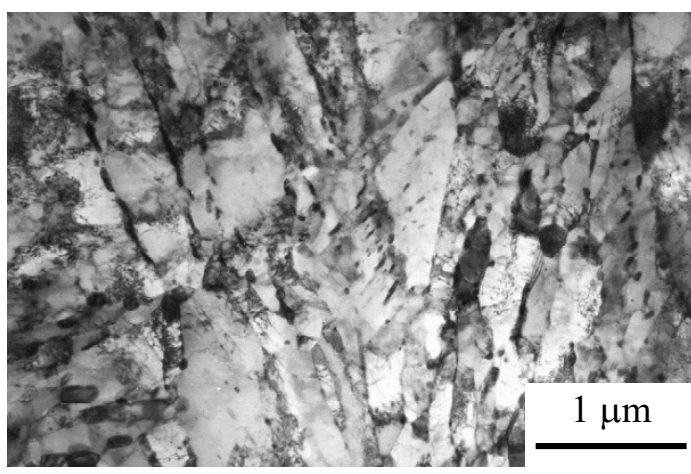

a

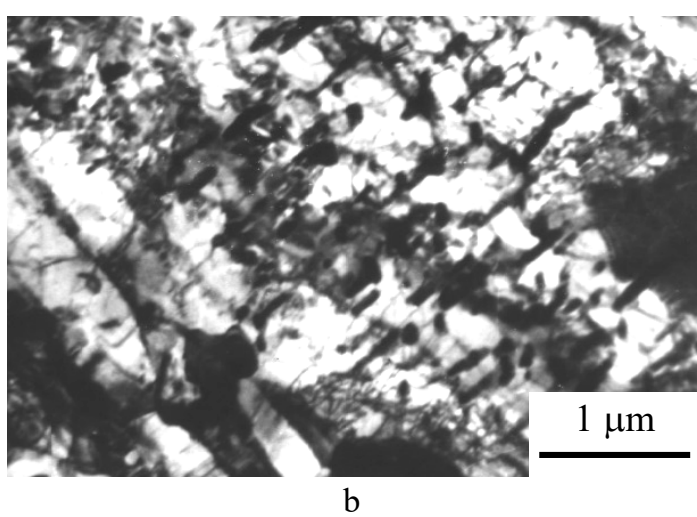

b

Fig. 8. The microstructure of $40 \mathrm{Kh}$ steel after quenching from 860 (a) and $1050{ }^{\circ} \mathrm{C}$ (b) and tempering at $600{ }^{\circ} \mathrm{C}$

The structure of the vast majority of antifriction alloys is subject to the Sharpie-Bochvar principle $[55,56]$, according to which the hardest microstructural components should be uniformly distributed in the form of isolated sections in a less hard and ductile matrix [57 - 60]. The effectiveness of materials with such a structure is proven by years of experience in their use in moving joints [61]. Therefore, when developing new wear-resistant metallic materials or forming friction surfaces, it is advisable to create structures like a composite material, that is, contain hard particles distributed in a certain way in a 


\section{Prediction of Tribological Properties of Structural Steels Using Artificial Neural Networks}

relatively soft matrix. Such particles can be, in particular, carbides of iron and alloying elements, complex carbides, and intermetallics [62].

The contact interaction during friction is accompanied by the processes of deformation and formation and destruction of frictional bonds in local areas of the surface, namely contact spots, the average diameter of which is $6 \ldots 30 \mu \mathrm{m}[63,64]$. Therefore, such an element of the microstructure, as the carbide phase, falls into the contact zone, and its behavior when applying external loads to varying degrees affects the resistance to contact fracture. At the end of the process of pre-working in the surface layer up to $10 \mu \mathrm{m}$ thick, an oriented fragmented microstructure is formed. The process of normal friction and wear without burrs and grasp is determined by the formation and preservation of a stable structure within the contact spots, which can quasi-elastically accept the load. The stability of the structure within the spots is due to its resistance, as well as the equilibrium of supply and removal of defects at the fragment boundaries [64].

As carbides are numerous obstacles to the movement of dislocations and thus contribute to the high strength of steel, the carbide phase, its size, and mechanical properties play a special role in the process of increasing the wear resistance [65 - 68]. Therefore, the time of existence of the interaction spots will be determined, on the one hand, by the stability of the carbides with respect to their decomposition during plastic deformation, and on the other by the size of the carbides, on which the stability term during deformation depends [69-71].

The increasing non-uniformity of the carbon distribution in $40 \mathrm{Kh}$ steel with increasing the quenching temperature to $1050{ }^{\circ} \mathrm{C}$ contributes to the increase in the size of high-carbon crystals of needleshaped martensite and the deposition of carbides stable to the decomposition during the plastic deformation. The last ones are deposited inside the martensite crystals at the microtwin boundaries during the tempering. They are larger than martensite packets. In this case, the friction surface becomes heterogeneous in mechanical properties due to the formation of separate sections, which can act as wear resistant contact spots and form the actual contact area. Therefore, the creation of a heterogeneous microstructure according to the Sharpie-Bochvar principle is one of the decisive factors in reducing the wear intensity of $40 \mathrm{Kh}$ steel.

The solution of specific materials science problems is based on the study of changes in the phase composition, microstructure and complex of mechanical properties depending on the operating conditions of the machine parts. Therefore, in addition to these internal factors, it is always necessary to take into account the temperature, pressure, presence or absence of lubricants, etc. These factors in the process of operation cause the transformation of the microstructure and stress state of the contact surfaces of the materials. In this case, the thermodynamic equilibrium is disturbed on the contacting surfaces, secondary structures are formed, selective dissolution of alloying elements, surface segregation, adsorption or desorption, reaction diffusion, etc. are also performed, which also affects the nature and mechanisms of tribological phenomena.

The course of the described processes can be regulated in different ways, in particular, by determining the types and morphology of the phases that would be appropriate to obtain at the contact surfaces, which will improve the tribological properties of moving joints $[54,72,73]$. To more precisely and diligently regulate the structure and phase composition of the surface layers of the investigated steel, which improve its tribological properties, the experimental data and computer simulation were combined. The solution of the tasks in the work requires consideration of many properties of materials. Therefore, it is advisable to use intelligent systems based on ANNs. Such systems are characterized by flexibility, and their functioning includes empirical, prediction-based skills.

In the work [74], using the values of quenching temperature $\left(t_{\text {гарт. }}\right)$ and microhardness of contacting friction surfaces $\left(\mathrm{H}_{\mu}\right)$ determined by sclerometer methods, the distance between their maximum values $\left(\mathrm{T}_{2}\right)$ and their average length $\left(\mathrm{L}_{\mathrm{cep}}\right)$, and the average size of carbides $\left(\mathrm{D} \kappa_{\mathrm{cep}}\right)$, a neural network was formed for prediction at $(i+1)$-th point according to the data of $(i-1)$-th and $i$-th points of three parameters $\left(H_{\mu}, T_{2}\right.$, $\mathrm{L}_{\mathrm{cep}}$ ). But the ANN variant obtained was capable of modeling only interpolation points. 


\section{Viktor Uvarov, Serhii Bespalov}

For modeling in both interpolation and extrapolation areas, the network architecture proposed in [74] and its teaching methodology were adapted. By applying the adapted ANN architecture (Fig. 9) due to the additional use of experimentally obtained values of the functional parameters of the surface $\mathrm{Sr}_{1}$ and $\mathrm{Sr}_{2}$ (Table 2), which characterize the function of the bearing capacity of the surface, tribological properties of $40 \mathrm{Kh}$ steel tempered after quenching from 860, 900, 950, 1050, 1160 and $1200^{\circ} \mathrm{C}$ were predicted (Fig. 10). An analysis of the dynamics of changing the parameters $\mathrm{Sr}_{1}$ and $\mathrm{Sr}_{2}$ shows that raising the quenching temperature to 900 and $950{ }^{\circ} \mathrm{C}$ reduces the bearing capacity of the $40 \mathrm{Kh}$ steel specimens. Quenching from $1050{ }^{\circ} \mathrm{C}$ leads to an increase in the bearing capacity, and further temperature rise to 1160 and $1200^{\circ} \mathrm{C}$ leads again to its decrease. The described changes in the functional parameters of the surface $\mathrm{Sr}_{1}$ and $\mathrm{Sr}_{2}$ obtained using the adapted ANN model, are similar to the simulation results reported in [74] and correlate with the results of wear resistance test of $40 \mathrm{Kh}$ steel obtained by the authors of the work [75].

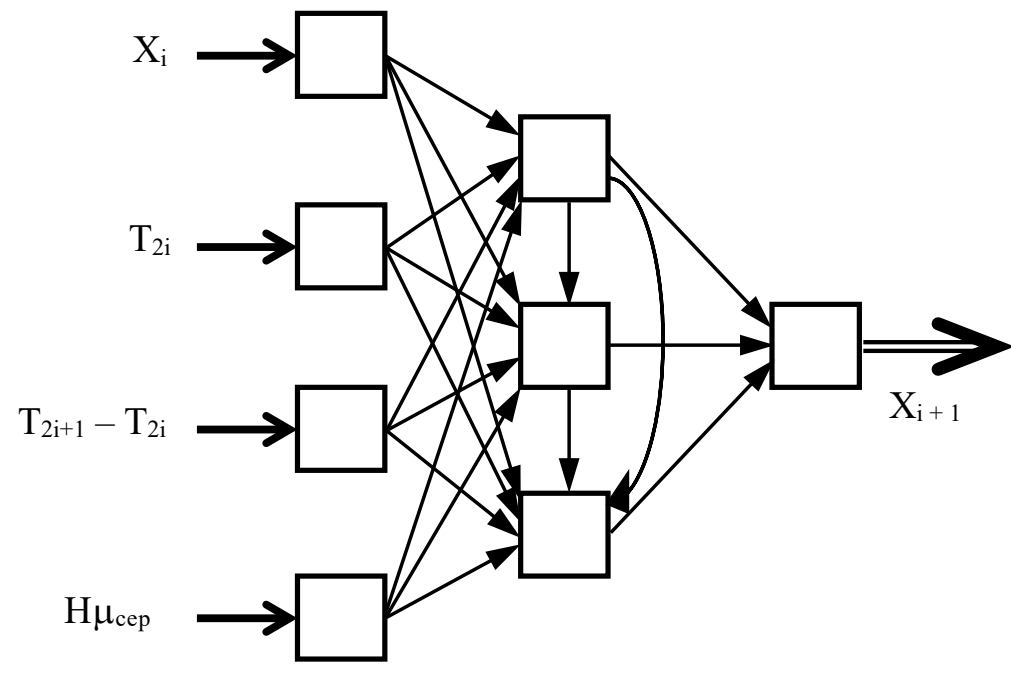

Fig. 9. Adapted neural network architecture: $X_{i}$ is the surface parameter at the $\mathrm{i}$-th scratch point; $\mathrm{X}_{\mathrm{i}+1}$ is the surface parameter at the

$\mathrm{i}+1$ scratch point; $\mathrm{H} \mu_{\text {cep }}$ is the average value of microhardness; $\mathrm{T}_{2}$ is the distance between extremes with maximum microhardness values

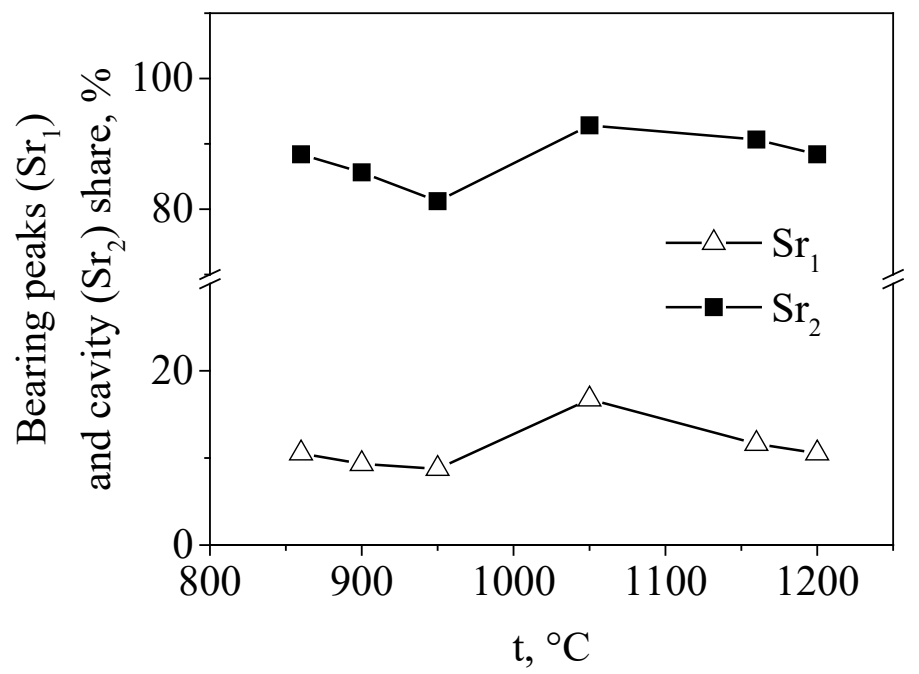

Fig. 10. Modeling and prediction of the functional parameters of the bearing capacity of the peaks $\left(\mathrm{Sr}_{1}\right)$ and valleys $\left(\mathrm{Sr}_{2}\right)$ on the $40 \mathrm{Kh}$ steel surface, depending on the quenching temperature $(\mathrm{t})$

\section{Conclusions}

It is found that the carbide phase morphology, which depends on the temperature conditions of heat treatment, affects the equilibrium roughness, structural-geometrical parameters, and bearing capacity of the $40 \mathrm{Kh}$ steel surface formed during contact interaction at friction, that, in turn, affects its tribological characteristics.

The architecture of the artificial neural network was adapted and the possibility of using neural network modeling to predict the change of structural-geometrical parameters characterizing the bearing capacity of the contact surfaces, depending on the quenching temperature of the investigated steel, was shown. 


\section{Prediction of Tribological Properties of Structural Steels Using Artificial Neural Networks}

According to the authors of the work, modeling using band calculations of the electronic structure $[76,77]$ of secondary structures that are formed during contact interaction and affect the tribological characteristics of materials, may also be promising.

\section{References}

[1] I. V. Kragelskii, Trenie i iznos [Friction and wear]. Moscow, Russia: Mashinostroenie Publ., 1968. [In Russian].

[2] D. N. Garkunov, Tribotekhnika (konstruirovanie, izgotovlienie i ekspluataciya mashin) [Tribotechnics (design, manufacturing and operation of machines)]. Moscow, Russia: MSKhA Publ., 2002. [In Russian].

[3] Yu. M. Pleskavskii, et al., "Belorusskaya nauchno-tekhnicheskaya programma "Tribotechnika" ["Belarusian scientific and technical program "Tribotechnology"], Trenie i iznos [Friction and wear], vol. 16, no. 3, pp. 404-415, 1995. [in Russian].

[4] V. P. Kogaev, Prochnost' $i$ iznosostoikost' detalei mashin [Strength and wear resistance of machine parts]. Moscow, Russia: Vystshaya Shkola Publ., 1991. [in Russian].

[5] P. Jost, "Mirovyie dostizheniya v oblasti tribologii" ["World achievements in the field of tribology"], Trenie i iznos [Friction and wear], vol. 7, no. 4, pp. 593-603, 1986. [in Russian].

[6] A. S. Pronikov, Parametricheskaya nadiozhnost' mashin [Machine parametric reliability]. Moscow, Russia: MGTU im. N.E. Baumana Publ., 2002. [in Russian].

[7] V. M. Pavlis'kyi, "Doslidzhennia prypratsiuvannia i znosu tsylindriv ta porshnevykh kilets' v period obkatky dvyhuniv" ["Investigation of the pre-working and wear of cylinders and piston rings during the run-in period of engines"], Naukovyi visnyk NAU [Scientific bulletin of NAU], vol. 4, pp. 160-164, 1998. [in Ukrainian].

[8] K. B. Katsov, and R. A. Khrunyk, "Novyie malonikelevyie vysokoprochnyie stali dlia burovykh dolot" ["New low nickel high strength steels for drill bits"], Fiziko-khimicheskaya mekhanika materialov [Physicochemical mechanics of materials], vol. 5, pp. 90-92, 1979. [in Russian].

[9] I. S. Kernytskyi, V. V. Kozub, and M. I. Pashechko, "Abrazyvna znosostiykist' evtektychnykh pokryttiv" ["Abrasive wear resistance of eutectic coatings"], Visnyk Derzhavnoho universytetu "L'vivs'ka politekhnika" "Optymizatsia vyrobnychykh protsesiv i tekhnichnyi kontrol' u mashynobuduvanni i pryladobuduvanni" [Bulletin of State University "Lviv Polytechnic" "Optimization of production processes and technical control in mechanical engineering and instrumentation”], vol. 371, pp. 93-96, 1999. [in Ukrainian].

[10] R. A. Khrunyk, "Rozrobka novykh oshchadnolehovanykh stalei dlia sharoshkovoho porodoruinuval'noho instrumentu" ["Development of new low-alloyed steels for conical rock-breaking tools"], Fizyko-khimichna mekhanika materialiv [Physicochemical mechanics of materials], vol. 36, no. 3, pp. 102-107, 2000. [in Ukrainian].

[11] A. V. Chichinadze, et al., Osnovy tribologii (trenie, iznos, smazka) [Fundamentals of tribology (friction, wear, lubrication)]. Moscow, Russia: Mashinostroenie Publ., 2001. [in Russian].

[12] S. Bakhodur, "Ekonomicheskoe znachenie iznosa materialov v sovremennom obshchestve" ["The economic importance of material wear in modern society"], Problemy treniya i smazki [Friction and lubrication problems], vol. 2, pp. 1-4, 1978. [in Russian].

[13] P. Jost, "Budushchee tribologii" ["The future of tribology"], Trenie i iznos [Friction and wear], vol. 12, no. 3, pp. 10-15, 1991. [in Russian].

[14] O. P. Datsyshyn, and V. V. Panasyuk, Kontaktna dovhovichnist' i ruinuvannia elementiv konstruktsii za tsyklichnoho navantazhennia [Contact durability and fracture of structural elements under cyclic loading]. Kyiv, Ukraine: Naukova Dumka Publ., 2018. [in Ukrainian].

[15] K. E. Aliyev, "Metody i sredstva modelirovaniya slabostrukturirovannykh informatsionnykh protsessov" ["Methods and tools for modeling poorly structured information processes"], M.S. thesis, Azerbaijan State Economic University, Baku, Azerbaijan, 2018. [in Russian].

[16] S. V. Aksenov, and V. B. Novoseltsev, Organiztsia $i$ ispol'zovanie neyronnych setei (metody $i$ technologii) [Organization and use of neural networks (methods and technologies)]. Tomsk, Russia: NTL Publ., 2006. [in Russian].

[17] S. Khaikin, Neyronnyie seti: Polnyi kurs [Neural networks: Full course]. Moscow, Russia: OOO "I. D. Williams" Publ., 2006. [in Russian].

[18] The basics of ANN. Neural networks. Electronic resource. Log access mode: https://neuralnet.info/book/.

[19] A neural network based on the "Functionality on multiple table functions" model. Electronic resource. Log access mode: http://www.uatur.com/html/neural_nets/Lecture4.htm\#base/.

[20] N. S. Liesna, Intelektual'nyi analiz danych [Intelligent data analysis]. Kharkiv, Ukraine: KhNURE Publ., 2003. [in Ukrainian]. 


\section{Viktor Uvarov, Serhii Bespalov}

[21] S. V. Pronin, "Primenenie iskusstvennykh neyronnykh sistem dlia modelirovania transportnykh sistem" ["Application of artificial neural systems for modeling of transport systems"], Avtomobil'nyi transport [Road transport], vol. 18, pp. 123-125, 2006. [in Russian].

[22] B. N. Bublik, Osnovy teorii upravleniya [Fundamentals of management theory]. Kyiv, Ukraine: Vyshcha Shkola Publ., 1975. [in Russian].

[23] T. Kvater, Neyromerezhevi informatsiyni tekhnologii kontroliu ta diahnostyky dynamichnykh obyektiv v umovakh nevyznachenosti [Neural network information technologies for control and diagnostics of dynamic objects in the face of uncertainty]. Lviv, Ukraine: Taras Soroka Publ., 2005. [in Ukrainian].

[24] V. I. Komashinskii, and D. A. Smirnov, Neyronnyie seti i ikh primenenie v sistemakh upravlenia i sviazi [Neural networks and their application in control and communication systems]. Moscow, Russia: Goriachaia Liniya - Telekom Publ., 2003. [in Russian].

[25] V. A. Terekhov, D. V. Yefimov, and I. Yu. Tyukin, Neyrosetevye sistemy upravlenia [Neural network management systems]. Moscow, Russia: Radiotechnika Publ., 2002. [in Russian].

[26] P. G. Krug, Neyronnyie seti i neyrokompyutery [Neural networks and neurocomputers]. Moscow, Russia: MEI Publ., 2002. [in Russian].

[27] D. Forsait, and J. Pons, Kompyuternoe zrenie. Sovremennyi podkhod [Computer vision. Modern approach]. Moscow, Russia: OOO “I. D. Williams” Publ., 2004. [in Russian].

[28] V. P. Boyun, "Intelektual'ni video systemy ta prystroi real'noho chasu" ["Intelligent real-time video systems and devices"], in Proc. Int. Conf. "Intelligent decision-making systems and applied aspects of information technologies", Evpatoria, Ukraine, May 15-18, 2007, pp. 101-107. [in Ukrainian].

[29] D. E. Bestens, V. M. Vandenberg, and D. Vud, Neyronnye seti i finansovyie rynki: priniatie reshenii v torgovykh operatsiyakh [Neural networks and financial markets: decision making in trading]. Moscow, Russia: TVP Publ., 1997. [in Russian].

[30] A. A. Yezhov, and S. A. Shumskii, Neyrokompyuting $i$ yego primenieniya v ekonomike $i$ bizniese [Neurocomputing and its applications in economics and business]. Moscow, Russia: MIFI Publ., 1998. [in Russian].

[31] K. H. Davies, R. Biddulph, and S. Balashek, "Automatic speech recognition of spoken digits", J. Acoust. Soc. Am., vol. 24, no. 6, pp. 637-642, 1952.

[32] U. Li, Metody avtomaticheskogo raspoznavaniya rechi [Automatic speech recognition techniques]. Moscow, Russia: Mir Publ., 1983. [in Russian].

[33] V. V. Berehovs'kyi, "Matematychne ta programne zabezpechennia avtomatyzovanoho proektuvannia system "Intelektual'noho budynku" ["Mathematical support and software for automated design of Intelligent Home systems"], Ph.D. dissertation, Lviv Polytechnic National University, Lviv, Ukraine, 2017. [in Ukrainian].

[34] N. Kasabov, "Introduction: Hybrid intelligent adaptive systems", International Journal of Intelligent Systems, vol. 6, pp. 453-454, 1998.

[35] V. V. Yemelyanov, V. V. Kurieychik, and V. M. Kurieychik, Teoriya i praktika evoliutsionnogo modelirovaniya [Theory and practice of evolutionary modeling]. Moscow, Russia: FIZMATLIT Publ., 2003. [in Russian].

[36] Y. Shoham, and K. Leyton-Brown, Algorithmic, game-theoretic, and logical foundations. London, UK: Cambridge University Press, 2009.

[37] S. Ossovskii, Neyronnyie seti dlia obrabotki informatsii [Neural networks for information processing]. Moscow, Russia: Finansy i Statistika Publ., 2002. [in Russian].

[38] V. Chaban, T. Kvater, and Ya. Bartman, "Diagnostyka elektromagnetnoho kola za dopomohoyu shtuchnoi neyronnoi merezhi" ["Diagnosis of electromagnetic circuit using artificial neural network"], in Proc. of the Scientific and Technical Conference on the 100th Anniversary of T. Gubenko "Electromechanics. Theory and practice", Lviv-Slavske, Ukraine, September 25-28, 1996, pp. 191-193. [in Ukrainian].

[39] A. Chaban, "Zastosuvannya shtuchnykh neyronnykh merezh dlia analizu elektromekhanichnykh system" ["Application of artificial neural networks for the analysis of electromechanical systems"], Elektrotekhnika $i$ elektromekhanika [Electrical engineering and electromechanics], no. 1, pp. 57-59, 2008. [in Ukrainian].

[40] Artificial neural networks. Electronic resource. Log access mode: http://masters.donntu.org/2007/fvti/yemeliyanenko/library/3.htm/.

[41] Z. Duriagina, and P. Tkachenko, "Vykorystannya shtuchnykh neyronnykh merezh dlia prohnozuvannya vlastyvostei poverkhni konstruktsiynykh materialiv" ["The use of artificial neural networks to predict the surface properties of structural materials"], Mashynoznavstvo [Mechanical Science], vol. 56, no. 2, pp. 29-31, 2002. [in Ukrainian]. 


\section{Prediction of Tribological Properties of Structural Steels Using Artificial Neural Networks}

[42] Z. Duriagina, P. Tkachenko, and T. Ivashko, "Neyromerezheve modeliuvannya vlastyvostei zakhysnykh poverkhnevykh shariv, stvorenykh lazernym lehuvannyam" ["Neural network modeling of properties of protective surface layers created by laser alloying"], Fizyko-khimichna mekhanika materialiv [Physicochemical mechanics of materials], vol. 38, no. 3 (special issue), pp. 585-588, 2002. [in Ukrainian].

[43] E. V. Kozlov, et al., "Vliyanie skorosti zakalki na strukturu i kolichestvennyie parametry martensitnogo prevrashcheniya $\mathrm{v}$ litoi konstruktsionnoi srednelegirovannoi stali" ["Effect of quenching rate on the structure and quantitative parameters of martensitic transformation in cast structural middle alloyed steel"], Fundamental'nyie problemy sovremennogo materialovedeniya [Fundamental problems of modern materials science], vol. 2, no. 1, pp. 118-123, 2005. [in Russian].

[44] Yu. F. Ivanov, and E. V. Kozlov, "Izotermicheskii otpusk zakalennoi sredneuglerodistoi malolegirovannoi stali. Kinetika obrazovaniya chastits tsemenita pri temperature $200{ }^{\circ} \mathrm{C}$ " ["Isothermal tempering of quenched medium-carbon low alloyed steel. Kinetics of the formation of cementite particles at a temperature of $200{ }^{\circ} \mathrm{C}$ "], Fundamental'nyie problemy sovremennogo materialovedeniya [Fundamental problems of modern materials science], vol. 3, no. 3, pp. 61-68, 2006. [in Russian].

[45] M. A. Tylkin, Spravochnik termista remontnoi sluzhby [Repair service thermist reference]. Moscow, Russia: Metallurgia Publ., 1981. [in Russian].

[46] Izmenenie mikrotviordosti tsarapaniyem almaznymi nakonechnikami [Change in microhardness by scratching with diamond tips], GOST 21318-82, 1983. [in Russian].

[47] P. V. Diachenko, Sovremennyie napravlienia v oblasti obespechenia vysokogo kachestva poverkhnosti detalei [Modern trends in the field of providing high quality surface parts]. Moscow, Russia: AN SSSR Publ., 1960. [in Russian].

[48] N. K. Myshkin, and M. I. Petrokovets, Trenie, smazka, iznos. Fizicheskie osnovy i tekhnicheskie prilozheniya tribologii [Friction, lubrication, wear. Physical foundations and technical applications of tribology]. Moscow, Russia: FIZMATLIT Publ., 2007. [in Russian].

[49] N. S. Pienkin, A. N. Pienkin, and V. M. Serbin, Osnovy tribologii i tribotekhniki [Fundamentals of tribology and tribotechnology]. Moscow, Russia: Mashinostroenie Publ., 2012. [in Russian].

[50] Surface roughness. Part 1: Surface and its parameters, ISO 4287/1, 1984.

[51] Rules and procedures for the measurement of surface parameters, ISO 4288, 1985.

[52] S. P. Yakovlieva, et al., "Povyshenie iznosostoikosti i relief poverkhnosti treniya ferritno-perlitnoi stali, nanostrukturirovannoi megaplasticheskoi deformatsiyey" ["Improving the wear resistance and friction surface relief of ferritic-pearlite steel, nanostructured by megaplastic deformation"], Fundamental'nyie issledovaniya. Razdel "Tekhnicheskiye nauki" [Basic research. Section "Engineering”], vol. 15, no. 10, pp. 3451-3455, 2013. [in Russian].

[53] N. A. Morozova, "Povyshenie iznosostoikosti tsilindricheslikh poverkhnostei detalei mashin vibroudarnym plasticheskim uprochneniem" ["Improving the wear resistance of cylindrical surfaces of machine parts by percussion plastic hardening"], Ph.D. dissertation, Siberian State University of Railway Engineering, Novosibirsk, Russia, 2005. [in Russian].

[54] P. Yu. Volosievich, and S. A. Bespalov, "Strukturoobrazovaniye i iznosostoykost' stali 40Kh" ["Structuring and wear resistance of $40 \mathrm{Kh}$ steel"], Metallofizika i noveyshiye tekhnologii [Metallophysics and advanced technologies], vol. 26, no. 5, pp. 691-701, 2004. [in Russian].

[55] A. A. Zhukov, G. I. Silman, and L. Z. Epshtein, "Struktura stali i chuguna i printsip Sharpi" ["Steel and cast iron structure and Charpy principle"], Izvestiya AN SSSR. Metally [Proceedings of the USSR Academy of Sciences. Metals], vol. 2, pp. 145-152, 1971. [in Russian].

[56] Metallurgical dictionary. Electronic resource. Log access mode: http://metallurgy_dictionary.academic.ru/.

[57] V. V. Iliushin, B. A. Potiekhin, and A. S. Khristoliubov, "Napravlieniye sozdaniya splavov skol'zheniya s povyshennymi tekhnologicheskimi svoystvami" ["Direction of creation of slip alloys with enhanced technological properties"], Lesa Rossii i khoziaystvo v nikh [Forests of Russia and the economy in them], vol. 44, no. 1, pp. 169171, 2013. [in Russian].

[58] G. G. Mukhin, et al., "Materialy v mashinostroenii" ["Materials in mechanical engineering"], in Mashinostroenie. Entsiklopediya v 40 tomakh, [Engineering. Encyclopedia in 40 volumes], vol. 2. Moscow, Russia: Mashinostroenie Publ., 2001. [in Russian].

[59] K. V. Frolov, Sovremennaya tribologiya: Itogi i perspektivy [Modern tribology: Results and prospects]. Moscow, Russia: LKI Publ., 2008. [in Russian].

[60] V. V. Iliushin, and B. A. Potiekhin, "Al'ternativnyi antifriktsionnyi material" ["Alternative antifriction material"], Lesa Rossii $i$ khoziaystvo v nikh [Forests of Russia and the economy in them], vol. 44, no. 1, pp. 166-168, 2013. [in Russian]. 


\section{Viktor Uvarov, Serhii Bespalov}

[61] A. I. Shpagin, Antifriktsionnyie splavy [Antifriction alloys]. Moscow, Russia: Metallurgizdat Publ., 1956. [in Russian].

[62] Yu. K. Mashkov, Tribologia konstruktsionnykh materialov [Tribology of engineering materials]. Omsk, Russia: OmGTU Publ., 1996. [in Russian].

[63] L. S. Rapoport, and L. M. Rybakova, "Vliyaniye strukturnogo sostoyaniya poverkhnostnykh sloyev na protsessy treniya i iznashivaniya" ["The influence of the structural state of surface layers on the processes of friction and wear"], Trenie i iznos [Friction and wear], vol. 8, no. 5, pp. 888-893, 1987. [in Russian].

[64] L. S. Rapoport, and L. M. Rybakova, "Vliyaniye strukturnogo sostoyaniya poverkhnostnykh sloyev na protsessy treniya i iznashivaniya" ["The influence of the structural state of surface layers on the processes of friction and wear"], Trenie i iznos [Friction and wear], vol. 8, no. 6, pp. 1038-1043, 1987. [in Russian].

[65] O. Yu. Yelagina, Tekhnologicheskiye metody povysheniya iznosostoikosti detalei mashin [Technological methods for increasing the wear resistance of machine parts]. Moscow, Russia: Universitetskaya Kniga Publ., 2009. [in Russian].

[66] M. L. Bernshtein, and V. A. Zaymovskii, Mekhanicheskiye svoistva metallov [The mechanical properties of metals]. Moscow, Russia: Metallurgia Publ., 1979. [In Russian].

[67] K. H. Zum Gahr, Microstrure and wear of materials. Amsterdam-Oxford-New York-Tokyo: Elsevier Science Publishers, 1987.

[68] B. N. Arzamasov, Tsirkuliatsionnyi metod polucheniya zharostoikikh i iznosostoikikh diffuzionnykh pokrytii [The circulation method of obtaining heat-resistant and wear-resistant diffusion coatings]. Moscow, Russia: Mashprom Publ., 1980. [In Russian].

[69] M. V. Belous, and V. T. Cherepin, "Izmenieniya v karbidnoi faze stali pod vliyaniyem kholodnoi plasticheskoi deformatsii" ["Changes in the carbide phase of steel under the influence of cold plastic deformation"], Fizika metallov i metallovedenie [Metal physics and metals science], vol. 12, p. 685, 1961. [in Russian].

[70] M. V. Belous, and V. T. Cherepin, "Izmenieniya v karbidnoi faze stali pod vliyaniyem kholodnoi plasticheskoi deformatsii. Raspad i grafitizatsiya vysokootpushchennoi stali" ["Changes in the carbide phase of steel under the influence of cold plastic deformation. Decomposition and graphitization of high tempered steel"], Fizika metallov i metallovedenie [Metal physics and metals science], vol. 14, no. 1, p. 48, 1962. [in Russian].

[71] N. A. Popova, "Evolutsia dislokatsionnogo ansamblia, vnutrennie polia napriazhenii i fazovyie prevrashchenia pri plasticheskoi deformatsii stalei s razlichnoi strukturoi" ["The evolution of a dislocation ensemble, internal stress fields, and phase transformations during plastic deformation of steels with different structures"], Ph.D. dissertation, Tomsk State University of Architecture and Civil Engineering, Tomsk, Russia, 2005. [in Russian].

[72] V. V. Matveyev, "Naplavka grebnei vagonnykh koles posle otzhiga poverkhnosti kataniya na vagonoremontnykh zavodakh Ukrainy" ["Repair flange surfacing of railway wheels after annealing of the tread surface at railway repair plants in Ukraine"], Avtomaticheskaya svarka [Automatic welding], vol. 6, pp. 42-48, 2005. [in Russian].

[73] P. Yu. Volosievich, and S. A. Bespalov, 'Mikrotviordost' poverkhnostei i yeyio sviaz' s temperaturoi zakalki i raspredeleniyem ugleroda v staliakh 40Kh i 40KhNM" ["Microhardness of surfaces and its relationship with quenching temperature and carbon distribution in steels 40Kh and 40KhNM"], Metallofizika i noveishiye tekhnologii [Metallophysics and advanced technologies], vol. 28, no. 12, pp. 1629-1638, 2006. [in Russian].

[74] V. M. Uvarov, and S. A. Bespalov, "Vykorystannia shtuchnykh neyronnykh merezh dlia vyrishennia trybolohichnykh zadach" ["Using artificial neural networks to solve tribological tasks"], Metaloznavstvo ta obrobka metaliv [Metals science and treatment of metals], vol. 90, no. 3, pp. 1-10, 2019. [in Ukrainian].

[75] A. A. Mukhammedov, "Prochnost' i iznosostoikost' v zavisimosti ot velichiny austenitnogo zerna i tonkoi struktury stali" ["Strength and wear resistance depending on the size of austenitic grain and the fine structure of steel"], Metallovedenie i termicheskaya obrabotka metallov [Metals science and heat treatment of metals], vol. 7, pp. 31-34, 1968. [in Russian].

[76] V. V. Tikhonovich, and V. N. Uvarov, "Vliyaniye aktivnykh elementov rabochei sredy na elektronnuyu strukturu i mekhanism deformatsii poverkhnostnykh sloyev metalla pri trenii" ["The influence of active elements of the working medium on the electronic structure and mechanism of deformation of the surface layers of metal during friction"], Uspekhi fiziki metallov [Advances in metal physics], vol. 12, no. 2, pp. 209-239, 2011. [in Russian].

[77] V. M. Uvarov, et. al., "Atomne rozuporiadkuvannia ta elektronna budova splavu Heuslera CoTiSb" ["Atomic disorder and electron structure of Heusler alloy CoTiSb"], Ukrains'kyi fizychnyi zhurnal [Ukrainian journal of physics], vol. 62, no. 2, pp. 106-111, 2017. [in Ukrainian]. 